\title{
THE BINDING OF THIOCYANATE TO ALBUMIN IN NORMAL HUMAN SERUM AND DEFIBRINATED BLOOD WITH REFERENCE TO THE DETERMINATION OF "THIOCYANATE SPACE" 1
}

\author{
BY I. HERBERT SCHEINBERG ${ }^{2}$ AND HENRY J. KOWALSKI ${ }^{3}$ \\ WITH THE TECHNICAL ASSISTANCE OF GLADYS M. LATSHAW \\ (From the Department of Chemistry, Massachusetts Institute of Technology, Cambridge, \\ Massachusetts, and the Department of Preventive Medicine, Harvard \\ Medical School, Boston)
}

(Submitted for publication October 22, 1949; accepted, December 12, 1949)

Since the report of Crandall and Anderson (1) in 1934, the distribution of thiocyanate ion in the body has been used as a measure of extracellular fluid volume. All such work has been based on the procedure of administering a known amount of a thiocyanate, and after an interval, measuring the concentration of thiocyanate in the serum. The amount of thiocyanate injected, or more accurately, the thiocyanate remaining in the body at this time, is divided by the serum concentration, and the resulting number is termed the "thiocyanate space." The assumptions usually made, implicitly or explicitly, in this procedure are that thiocyanate is not metabolized and does not penetrate cells except red cells, that equilibrium exists between serum and extravascular thiocyanate, and that the thiocyanate concentration is essentially the same in the extravascular fluid as it is in the serum. The work reported in this paper shows that the latter assumption is wrong and that the error resulting from its use is great.

Methods of determining serum thiocyanate measure total thiocyanate since they depend on calibration curves made from known amounts of thiocyanate in serum (2) or can be shown to recover about $100 \%$ of thiocyanate added to serum (3). If any thiocyanate is bound to a non-diffusible component of blood, such as protein, then the bound portion will not be free to diffuse out of the vascular compartment. Accordingly, the

\footnotetext{
1 Expenses of this study were in part defrayed by Research Grant H177 from the National Heart Institute, U. S. Public Health Service.

2 Member, Society of Fellows, Harvard University; Research Associate, Department of Chemistry, Massachusetts Institute of Technology.

3 Research Fellow in Preventive Medicine, Harvard Medical School.
}

total thiocyanate concentration in the serum will be higher than that in the extravascular fluid and the value obtained for the "thiocyanate space" will be smaller than the extravascular space. Lavietes, Bourdillon and Klinghoffer (4) suggested in 1936 that perhaps $10 \%$ of the thiocyanate present in blood might be bound to protein. In 1939, Rosenbaum and Lavietes (5) performed ultrafiltration and dialysis experiments with serum and thiocyanate, and their results indicated that in the range used in clinical experiments, as much as $45 \%$ of the thiocyanate in serum was bound, and not diffusible through a semipermeable membrane.

Work done in part by one of us, and published elsewhere (6), demonstrated that human serum albumin binds thiocyanate according to the law of mass action. Binding is used here to denote a combination of thiocyanate ion with albumin which is analogous to the combination of the anion of any weak acid, such as acetate, with hydrogen ion. From this work it might be expected that under the conditions of clinical use of thiocyanate, the amount bound to albumin would be great. The experiments reported below confirm this, and show that the conclusions derived from the previous study of an albumin-water-sodium thiocyanate system may be applied directly to blood or serum to determine the fraction of the total thiocyanate which is free to diffuse across a semipermeable membrane. The application of these results will make the calculation of the "thiocyanate space" more accurate, but will not determine the relation of this space to extracellular fluid volume. That relation will depend upon the quantity of extravascular albumin, and upon the extent to which thiocyanate enters cells. 


\section{METHODS}

Experiments were performed on normal human serum and on defibrinated blood. A cellophane sac containing $20 \mathrm{ml}$. of serum or blood and a Pyrex bead $15 \mathrm{~mm}$. in diameter was placed in a Pyrex test tube, $200 \times 25 \mathrm{~mm}$. Each test tube also contained $40 \mathrm{ml}$. of 0.15 molar sodium chloride solution containing a known amount of sodium thiocyanate. Control measurements, with 0.15 molar sodium chloride replacing the serum or blood, were also made at each thiocyanate concentration.

Each test tube was stoppered tightly, and placed in a holder which turned it end over end every eight seconds in a room maintained at $2.0 \pm 1.0^{\circ} \mathrm{C}$. The Pyrex bead, rolling from one end of the cellophane sac to the other, stirred its contents, and the motion of the sac stirred the outside solution. After 46 hours the volumes of the outside and inside solutions were measured to $\pm 1 \mathrm{ml}$. and the concentration of thiocyanate in the outside, protein-free solution was determined by the method of Crandall and Anderson (1) as modified by Rutstein and his co-workers (2). No flocculation was ever noted on the addition of trichloracetic acid but several solutions became opalescent indicating a slight leakage of protein. The concentrations of thiocyanate solutions used in initially filling the test tubes were also checked in the same manner having first been standardized against silver nitrate.

The total protein concentration of the serum and blood was determined by a modification of Pregl's method (7). The serum contained $7.76 \mathrm{gms}$. of protein per $100 \mathrm{ml}$., and the blood, the hematocrit of which was 43 , contained 8.51 gms. of serum proteins per $100 \mathrm{ml}$. of serum. ${ }^{4}$ The albumin concentration of the serum, determined by electrophoresis, ${ }^{4}$ and by the antibody titration method of Gitlin, Davidson and Wetterlow (8), was $52 \%$ of the total protein, or 4.03 gms. per $100 \mathrm{ml}$., by both methods. It was assumed that albumin also constituted $52 \%$ of the serum proteins of the blood. The water content of inside and outside solutions was determined by drying aliquots to constant weight at $106^{\circ} \mathrm{C}$.

From the total water content of the system, the concentration of thiocyanate ion in the outside solution, and the total amount of thiocyanate in the system, the amount of thiocyanate bound in serum or blood was calculated as follows. Let,

$n^{0}=$ total number of moles of thiocyanate in system,

$n_{c}=$ number of moles of thiocyanate bound to cellophane as determined in control measurement,

$n_{b}=$ number of moles of bound thiocyanate in serum or blood,

$g=$ kilograms of water,

( ) denote concentration of unbound ion in moles per kilogram of water.

4 These determinations were kindly done for us by Mr. M. J. E. Budka, and Miss Constance Qua, of the Department of Physical Chemistry, Harvard Medical School, and by Miss G. M. Rourke, of the Massachusetts General Hospital.
Primed quantities refer to the outside, protein-free solution.

Unprimed quantities refer to the inside solution containing serum or blood. Define,

$$
\Delta n=\left[n^{0}-n_{c}\right]-\left[g+g^{\prime}\right]\left(\mathrm{SCN}^{-}\right)^{\prime} .
$$

Then, inside the membrane,

$$
\begin{aligned}
\begin{aligned}
\left(\mathrm{Na}^{+}\right)=\frac{\left[n^{0}-n_{c}\right]-g^{\prime}\left(\mathrm{SCN}^{-}\right)^{\prime}}{g} & +(0.15) \\
& =(0.15)+\left(\mathrm{SCN}^{-}\right)^{\prime}+\frac{\Delta n}{g} \\
\left(\mathrm{SCN}^{-}\right)=\frac{\left[n^{0}-n_{c}\right]-g^{\prime}\left(\mathrm{SCN}^{-}\right)^{\prime}-n_{b}}{g} & \\
& =\left(\mathrm{SCN}^{-}\right)^{\prime}+\frac{\Delta n-n_{b}}{g}
\end{aligned}
\end{aligned}
$$

and, outside the membrane,

$$
\begin{aligned}
\left(\mathrm{Na}^{+}\right)^{\prime} & =(0.15)+\left(\mathrm{SCN}^{-}\right)^{\prime} \\
\left(\mathrm{SCN}^{-}\right)^{\prime} & =\left(\mathrm{SCN}^{-}\right)^{\prime} .
\end{aligned}
$$

The Donnan equilibrium, stating that the product of the concentrations $^{5}$ of sodium and thiocyanate inside the membrane is equal to this product outside the membrane, is

$$
\begin{aligned}
{\left[(0.15)+\left(\mathrm{SCN}^{-}\right)^{\prime}\right.} & \left.+\frac{\Delta n}{g}\right]\left[\left(\mathrm{SCN}^{-}\right)^{\prime}+\frac{\Delta n-n_{b}}{g}\right] \\
= & {\left[(0.15)+\left(\mathrm{SCN}^{-}\right)^{\prime}\right]\left[\left(\mathrm{SCN}^{-}\right)^{\prime}\right] }
\end{aligned}
$$

If we divide both sides by $\left[(0.15)+\left(\mathrm{SCN}^{-}\right)^{\prime}\right]$ we obtain

$$
\left[1+\frac{\frac{\Delta n}{g}}{(0.15)+\left(\mathrm{SCN}^{-}\right)^{\prime}}\right]\left[\left(\mathrm{SCN}^{-}\right)^{\prime}+\frac{\Delta n-n_{b}}{g}\right]=\left(\mathrm{SCN}^{-}\right)^{\prime}
$$

In the experiments reported in this paper the value of the first factor on the left is never greater than 1.027 and in the range of thiocyanate concentration close to that used clinically the value of this factor is 1.003 . Therefore we will never make a serious error by replacing this factor by 1 . Then equation $1 a$ reduces to $n_{b}=\Delta n$. Since the expression for $\Delta \boldsymbol{n}$ involves only experimentally determined quantities, we are thus enabled to calculate $n_{b}$, the number of moles of thiocyanate bound in serum or blood. In the preceding calculations we have assumed that the sodium ion is not appreciably bound $(6,9)$.

\section{RESULTS}

The results are given in Table I. Part A lists the results for the controls which had only 0.15 molar sodium chloride inside the membrane. In these controls the thiocyanate concentration is de-

5 The Donnan equilibrium actually involves the product of the activities of ions but we use concentrations by assuming the activity coefficients of the ions are the same on both sides of the membrane. 
termined on the inside solution as well as the outside. The average deviation between the two values was $1.4 \%$ and indicates that equilibrium was attained. In these control tubes all the thiocyanate is free except that bound to cellophane. The average value of the duplicates for $n_{b}$ in this part is used as $n_{c}$, the number of moles bound to cellophane, for the corresponding concentration of thiocyanate in Parts B and C. In Part B, $20 \mathrm{ml}$. of serum, and in Part C, $20 \mathrm{ml}$. of defibrinated blood, were placed in the membrane.

The column headed "Fraction bound" is the total number of moles of thiocyanate bound in serum or blood divided by the total number of moles of thiocyanate inside the membrane at equi- librium. In the concentration range which is close to that used in the clinical determination of "thiocyanate space," about 0.001 molar, approximately a third of the total thiocyanate is bound. The large variation in the fraction bound of the most dilute solutions with serum, which are duplicates, is due to the small absolute value of $n_{b}$ and the resulting large error in its determination.

$\bar{\nu}$ is the total number of moles of bound thiocyanate divided by the total number of moles of albumin in the system. The latter is calculated from the albumin content of the serum or blood and a molecular weight of 69,000 (10) for albumin. $\bar{\nu}$, then, is the average number of thiocyanate ions bound to each albumin molecule if albumin is the

TABLE I

Binding of thiocyanate in normal human serum and defibrinated blood

\begin{tabular}{|c|c|c|c|c|c|c|c|c|c|}
\hline & Tube no. & $\begin{array}{c}\text { Total moles } \\
\text { thiocyanate } \\
\text { in system }\end{array}$ & $\begin{array}{c}\left(\mathrm{SCN}^{-}\right)^{\prime} \\
\mathrm{moles} / \mathrm{kgg} . \\
\mathrm{H}_{2} \mathrm{O}\end{array}$ & $\begin{array}{c}(\mathrm{SCN}-) \\
\text { moles/kg. } \\
\mathrm{H}_{2} \mathrm{O}\end{array}$ & $g+g^{\prime} \mathrm{kg}$ & $\mathbf{g}$ kg. & $n_{b}=\Delta n$ & $\begin{array}{l}\text { Fraction } \\
\text { bound }\end{array}$ & $\bar{\nu}$ \\
\hline \multirow{5}{*}{$\begin{array}{l}\text { A-Saline } \\
\text { Controls }\end{array}$} & $\begin{array}{l}13 \\
12\end{array}$ & $\begin{array}{l}\times 10^{4} \\
8.25 \\
8.25\end{array}$ & $\begin{array}{c}\times 10^{3} \\
13.52 \\
13.26\end{array}$ & $\begin{array}{c}\times 10^{3} \\
13.19 \\
13.26\end{array}$ & $\begin{array}{l}0.0603 \\
0.0597\end{array}$ & $\begin{array}{l}0.0208 \\
0.0202\end{array}$ & $\begin{array}{c}\times 10^{4} \\
0.104 \\
0.325\end{array}$ & & \\
\hline & $\begin{array}{l}28 \\
29\end{array}$ & $\begin{array}{l}2.03 \\
2.03\end{array}$ & $\begin{array}{l}3.364 \\
3.258\end{array}$ & $\begin{array}{l}3.330 \\
3.224\end{array}$ & $\begin{array}{l}0.0591 \\
0.0595\end{array}$ & $\begin{array}{l}0.0199 \\
0.0203\end{array}$ & $\begin{array}{l}0.041 \\
0.091\end{array}$ & & \\
\hline & $\begin{array}{l}33 \\
34\end{array}$ & $\begin{array}{l}0.802 \\
0.802\end{array}$ & $\begin{array}{l}1.244 \\
1.231\end{array}$ & $\begin{array}{l}1.231 \\
1.213\end{array}$ & $\begin{array}{l}0.0575 \\
0.0597\end{array}$ & $\begin{array}{l}0.0196 \\
0.0203\end{array}$ & $\begin{array}{l}0.087 \\
0.067\end{array}$ & & \\
\hline & $\begin{array}{l}21 \\
26\end{array}$ & $\begin{array}{l}0.410 \\
0.410\end{array}$ & $\begin{array}{l}0.6288 \\
0.6137\end{array}$ & $\begin{array}{l}0.6222 \\
0.6240\end{array}$ & $\begin{array}{l}0.0598 \\
0.0597\end{array}$ & $\begin{array}{l}0.0203 \\
0.0209\end{array}$ & $\begin{array}{l}0.0341 \\
0.043\end{array}$ & & \\
\hline & $\begin{array}{l}15 \\
16\end{array}$ & $\begin{array}{l}0.0817 \\
0.0817\end{array}$ & $\begin{array}{l}0.1146 \\
0.1080\end{array}$ & $\begin{array}{l}0.1084 \\
0.1071\end{array}$ & $\begin{array}{l}0.0582 \\
0.0597\end{array}$ & $\begin{array}{l}0.0200 \\
0.0203\end{array}$ & $\begin{array}{l}0.015 \\
0.017\end{array}$ & & \\
\hline \multirow{5}{*}{ B-Serum } & $\begin{array}{l}3 \\
8\end{array}$ & $\begin{array}{l}8.25 \\
8.25\end{array}$ & $\begin{array}{l}12.14 \\
12.39\end{array}$ & & $\begin{array}{l}0.0589 \\
0.0576\end{array}$ & $\begin{array}{l}0.0230 \\
0.0220\end{array}$ & $\begin{array}{l}0.890 \\
0.902\end{array}$ & $\begin{array}{l}0.24 \\
0.25\end{array}$ & $\begin{array}{l}7.7 \\
7.7\end{array}$ \\
\hline & $\begin{array}{l}23 \\
25\end{array}$ & $\begin{array}{l}2.03 \\
2.03\end{array}$ & $\begin{array}{l}2.764 \\
2.772\end{array}$ & & $\begin{array}{l}0.0578 \\
0.0587\end{array}$ & $\begin{array}{l}0.0226 \\
0.0235\end{array}$ & $\begin{array}{l}0.365 \\
0.335\end{array}$ & $\begin{array}{l}0.37 \\
0.34\end{array}$ & $\begin{array}{l}3.1 \\
2.8\end{array}$ \\
\hline & $\begin{array}{l}35 \\
36\end{array}$ & $\begin{array}{l}0.802 \\
0.802\end{array}$ & $\begin{array}{l}1.036 \\
1.019\end{array}$ & & $\begin{array}{l}0.0589 \\
0.0584\end{array}$ & $\begin{array}{l}0.0233 \\
0.0226\end{array}$ & $\begin{array}{l}0.114 \\
0.129\end{array}$ & $\begin{array}{l}0.32 \\
0.36\end{array}$ & $\begin{array}{l}1.0 \\
1.2\end{array}$ \\
\hline & $\begin{array}{l}19 \\
20\end{array}$ & $\begin{array}{l}0.410 \\
0.410\end{array}$ & $\begin{array}{l}0.5137 \\
0.488\end{array}$ & & $\begin{array}{l}0.0582 \\
0.0576\end{array}$ & $\begin{array}{l}0.0230 \\
0.0226\end{array}$ & $\begin{array}{l}0.0704 \\
0.0903\end{array}$ & $\begin{array}{l}0.37 \\
0.45\end{array}$ & $\begin{array}{l}0.6 \\
0.8\end{array}$ \\
\hline & $\begin{array}{r}4 \\
11\end{array}$ & $\begin{array}{l}0.0817 \\
0.0817\end{array}$ & $\begin{array}{l}0.1026 \\
0.0943\end{array}$ & & $\begin{array}{l}0.0586 \\
0.0575\end{array}$ & $\begin{array}{l}0.0225 \\
0.0226\end{array}$ & $\begin{array}{l}0.0054 \\
0.0113\end{array}$ & $\begin{array}{l}0.2 \\
0.4\end{array}$ & $\begin{array}{l}0.05 \\
0.1\end{array}$ \\
\hline \multirow{5}{*}{ C-Blood } & $\begin{array}{l}5 \\
7\end{array}$ & $\begin{array}{l}8.25 \\
8.25\end{array}$ & $\begin{array}{l}12.24 \\
12.61\end{array}$ & & $\begin{array}{l}0.0578 \\
0.0578\end{array}$ & $\begin{array}{l}0.0216 \\
0.0210\end{array}$ & $\begin{array}{l}0.957 \\
0.755\end{array}$ & $\begin{array}{l}0.27 \\
0.22\end{array}$ & $\begin{array}{l}13.2 \\
10.3\end{array}$ \\
\hline & 22 & 2.03 & 3.007 & & 0.0571 & 0.0216 & 0.244 & 0.27 & 3.3 \\
\hline & 31 & 0.802 & 1.097 & & 0.0568 & 0.0215 & 0.101 & 0.30 & 1.4 \\
\hline & $\begin{array}{l}27 \\
30\end{array}$ & $\begin{array}{l}0.410 \\
0.410\end{array}$ & $\begin{array}{l}0.5337 \\
0.5299\end{array}$ & & $\begin{array}{l}0.0567 \\
0.0572\end{array}$ & $\begin{array}{l}0.0208 \\
0.0211\end{array}$ & $\begin{array}{l}0.069 \\
0.068\end{array}$ & $\begin{array}{l}0.38 \\
0.38\end{array}$ & $\begin{array}{l}1.0 \\
1.0\end{array}$ \\
\hline & 17 & 0.0817 & 0.1077 & & 0.0562 & 0.0201 & 0.00512 & 0.2 & 0.1 \\
\hline
\end{tabular}


only component of serum or blood which binds thiocyanate. This will be discussed further below.

\section{DISCUSSION}

The results presented above, as well as the work of Rosenbaum and Lavietes (5), show that some component of blood binds thiòcyanate and maintains a higher concentration in the blood than on the other side of a semipermeable membrane.

Human serum albumin, which has been made available in crystalline form (10), has been shown to combine specifically with several kinds of inorganic anions including, among others, chloride, bromide, and thiocyanate $(6,9,11-14)$. By experiments similar to those described above, and by use of electromotive force measurements, the binding of anions in a solution containing only crystalline human serum albumin, water, and the sodium salt of the anion was quantitatively studied $(6,9)$. The results were well described by assuming that albumin contained many groups or points with different affinities for different anions, and that many of these groups had essentially the same affinity for a given anion. In the quantitative treatment given in the papers mentioned it was necessary to take account of the fact that successive anions were less readily bound than their predecessors because of the electrostatic repulsion of the anions already bound toward any newcomers. No difference in binding could be shown at $4^{\circ} \mathrm{C}$. or room temperature $\left(20-25^{\circ} \mathrm{C}\right.$. $)$.

The equations which describe these results, and which allow $\bar{\nu}$ to be calculated as a function of the free anion concentration $(A)$, are of the form $(6,9)$

$$
\bar{\nu}=\sum_{i} \frac{n_{i} k_{i} \gamma(A) e^{-2 w \bar{z} P^{z_{A}}}}{1+k_{i} \gamma(A) e^{-2 w \bar{z} P^{z} A}},
$$

where the sum is to be taken over as many terms as there are sets of groups on albumin. Thus each $n_{i}$ is the number of groups on albumin in the $i$ th set, all of which react with a small anion $A$ with an intrinsic association constant $k_{i}$. The concentration of $A$ ions in moles per kilogram of water is $(A) ; \dot{\gamma}$, the activity coefficient of $A$ ions, and $w$, may be calculated from the Debye-Hückel theory $(15,16)$ as a function, chiefly, of the ionic strength of the solution; $\bar{z}_{P}$ is the average charge on the protein molecule, and $z_{A}$ is the charge on an $A$ ion. The $n$ 's and $k$ 's were evaluated from the experimental results given in these papers $(6,9)$.

For thiocyanate equation 2 has only two terms which means that two different sets of groups are sufficient to describe the results obtained in the albumin-water-sodium thiocyanate system over the concentration range from $\left(\mathrm{SCN}^{-}\right)=2 \times 10^{-5}$ to 0.7 molar (6). The first set consists of 10 groups which bind thiocyanate with an intrinsic association constant of 1000 ; the second set has 30 groups with a constant of 25 . Thus equation 2 for thiocyanate and albumin becomes

$$
\begin{aligned}
& \bar{\nu}=\frac{[10](1000) \gamma\left(\mathrm{SCN}^{-}\right) e^{-2 w \bar{z}_{P} z_{A}}}{1+[1000] \gamma\left(\mathrm{SCN}^{-}\right) e^{-2 w \bar{z}^{z_{2}} \mathrm{~A}}} \\
& +\frac{[30][25] \gamma\left(\mathrm{SCN}^{-}\right) e^{-2 w \bar{z}_{P^{z}}}}{1+[25] \gamma\left(\mathrm{SCN}^{-}\right) e^{-2 w \bar{z}_{P_{A}}}}
\end{aligned}
$$

In blood or serum it is necessary to alter equation 3 to take account of the fact that chloride ion is also bound to albumin in competition with thiocyanate $(9,13)$. We have neglected binding of any other anions since chloride is present to such excess over other anions. At this $\mathrm{pH}$, in 0.15 molar sodium chloride, 19 hydrogen ions are lost and six chloride ions bound by each albumin molecule $(9,12)$, which gives albumin a negative charge of about 25 . As the thiocyanate concentration is increased, bound thiocyanate largely displaces bound chloride $(9,13)$ and the total charge on albumin remains sufficiently constant so that we have assumed it to be -25.6 over the range of thiocyanate concentrations covered in the present work. $^{6}$ The resulting equation is,

$$
\begin{gathered}
\vec{\nu}=\frac{[10][1000] \gamma\left(\mathrm{SCN}^{-}\right) e^{-1.568}}{1+\left[[1000]\left(\mathrm{SCN}^{-}\right)+[44](0.15)\right] \gamma e^{-1.568}} \\
+\frac{[30][25] \gamma\left(\mathrm{SCN}^{-}\right) e^{-1.568}}{1+\left[[25]\left(\mathrm{SCN}^{-}\right)+[1.1](0.15)\right] \gamma e^{-1.568}}
\end{gathered}
$$

From equation 4 it is possible to construct a curve giving $\bar{\nu}$ as a function of $-\log \left(\mathrm{SCN}^{-}\right)$. This is the curve in Figure 1 and, of course, is independent of the experimental results reported in this paper.

In order to compare this curve with the experimental values determined in the present study, the observed values of $\bar{\nu}$ for serum and blood are also plotted against $-\log \left(\mathrm{SCN}^{-}\right)$in Figure 1. The

6 The calculated charge is -25.1 at $\left(\mathrm{SCN}^{-}\right)=0.0001$; -25.6 at $\left(\mathrm{SCN}^{-}\right)=0.001$; and -27.7 at $\left(\mathrm{SCN}^{-}\right)=0.01$. 


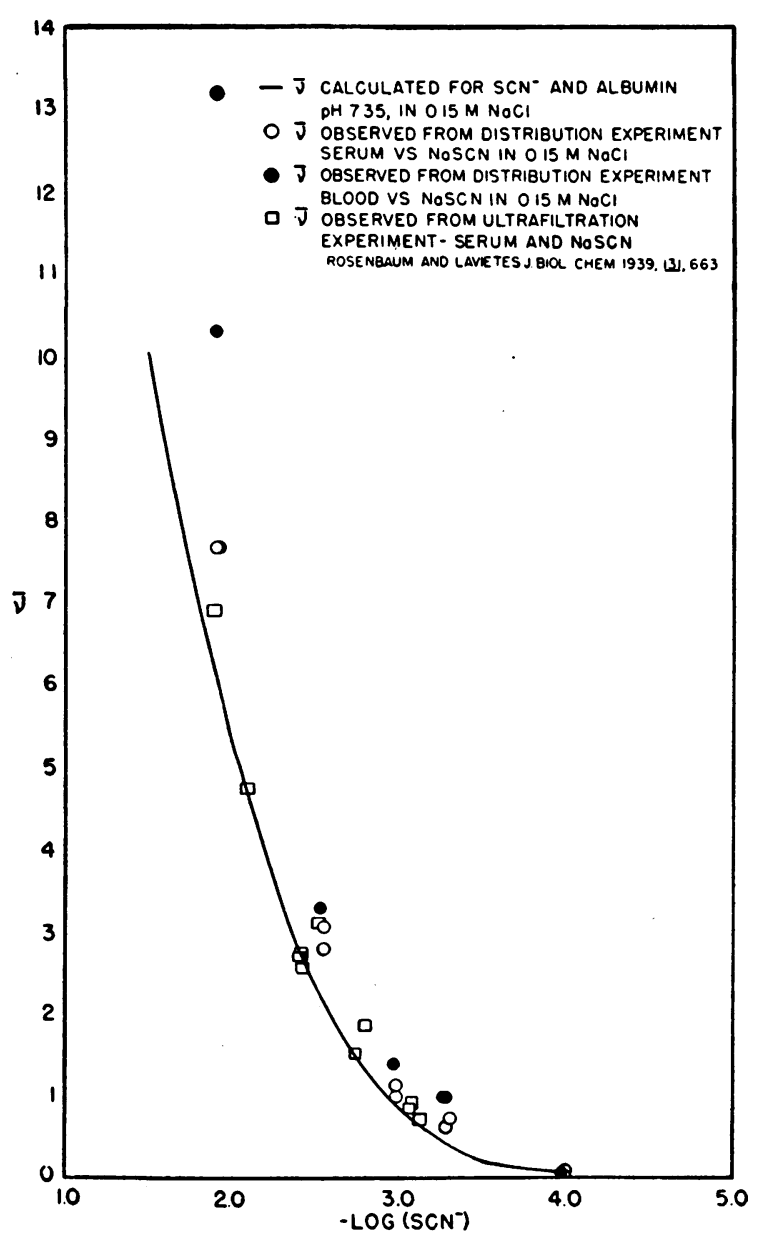

Fig. 1. The Binding of Thiocyanate Ions in Normal Human Serum and Defibrinated Blood ComPared to the Binding of Thiocyanate Ions in Solutions of Crystalline Human Serum Albumin

open circles are the experimental values found in serum and given in Table $I$. These serum values are parallel to the curve but are consistently slightly above it. Since the experimental $\bar{\nu}$ 's were calculated by dividing the total number of moles of bound thiocyanate by the total number of moles of albumin in the system, the experimental points should have fallen on the curve if our assumptions are correct, and if albumin is the only component of serum which binds thiocyanate. If some other serum component also binds thiocyanate the experimental points will fall above the curve. The magnitude of the deviations of the points from the curve suggests that almost all the bound thiocyanate is bound to albumin but that a small amount of thiocyanate appears to be bound to some other component of normal serum. This additional bound thiocyanate is equivalent to about $10 \%$ of the free thiocyanate over the range of concentrations covered in the present experiments.

The filled circles in Figure 1 represent the experimental values found for the defibrinated blood, again calculated as though only the albumin is binding thiocyanate. These also lie higher than the curve and higher than the serum results suggesting that some component of red cells, probably hemoglobin, binds thiocyanate also.

Finally the experiments of Rosenbaum and Lavietes (5) may be compared with ours. By ultrafiltration of normal human serum containing sodium thiocyanate through a cellophane membrane they were able to determine the concentration of free thiocyanate in the serum since this is ultrafilterable. From this and the total thiocyanate in the serum they calculated the amount bound. If their normal human serum is assumed to contain the same amount of albumin as ours ( 4.03 gms. per $100 \mathrm{ml}$. or 43.3 gms. per kilogram of water), values of $\bar{\nu}$ can be calculated from the results in their Table $I$. These are the open squares of Figure 1 and the agreement with the curve is excellent. The agreement is so good as to suggest that our conclusion that a small amount of thiocyanate is bound to another component of serum in addition to albumin is unnecessary. However, since this agreement depends on the assumption of the albumin content of their serum, we have preferred to give greater weight to our experiments in which the albumin concentration of the serum was measured. The ultrafiltration data do confirm our major conclusion that binding to albumin accounts for almost all of the thiocyanate bound in serum.

The essential agreement of these results with the curve in Figure 1 indicates that the equation derived from a study of systems containing only human serum albumin, sodium thiocyanate, and water may be used to determine how much thiocyanate is bound in serum.

How may these results be used in studying the distribution of thiocyanate in the body? We wish to know how much of the total thiocyanate in the serum is bound and how much is free, for it is the concentration of the latter which is equal to the concentration in the extravascular space at equilibrium. Since $\bar{\nu}$ is the average number of 
moles of thiocyanate bound to each mole of albumin, then, if $m$ is the concentration of albumin, $m$ is the concentration of bound thiocyanate. If $\left(\mathrm{SCN}^{-}\right)$is the free concentration and $t$ is the total concentration of thiocyanate it is clear that

$$
\left(\mathrm{SCN}^{-}\right)+\bar{\nu} m=t
$$

Now it is relatively simple to determine the total thiocyanate in serum (3). The concentration of albumin in the serum, $m$, is also readily determined (8) and since equation 4 relates to $\left(\mathrm{SCN}^{-}\right)$, equation 5 is left with one unknown, and we can solve it for the concentration of free thiocyanate. Working with equation 4 is cumbersome, and we may simplify the procedure with only slight loss of accuracy. If we perform the indicated arithmetic and divide equation 4 by $\left(\mathrm{SCN}^{-}\right)$we obtain

$$
\frac{\bar{\nu}}{\left(\mathrm{SCN}^{-}\right)}=\frac{787}{1+78.7\left(\mathrm{SCN}^{-}\right)}+\frac{118}{1+3.95\left(\mathrm{SCN}^{-}\right)}
$$

This may be substituted in equation 5 to give

$$
\left(\mathrm{SCN}^{-}\right)=\frac{t}{1+m\left[\frac{787}{1+78.7\left(\mathrm{SCN}^{-}\right)}+\frac{118}{1+3.95\left(\mathrm{SCN}^{-}\right)}\right]}
$$

Since our experiments with serum indicate that another component of serum in addition to albumin binds thiocyanate in an amount equivalent to $10 \%$ of the free thiocyanate, the value of $\left(\mathrm{SCN}^{-}\right)$given by equation 7 will be about $10 \%$ too high. The actual value of $\left(\mathrm{SCN}^{-}\right)$will be

$$
\left(\mathrm{SCN}^{-}\right)=\frac{0.9 t}{1+m\left[\frac{787}{1+78.7\left(\mathrm{SCN}^{-}\right)}+\frac{118}{1+3.95\left(\mathrm{SCN}^{-}\right)}\right]}
$$

At very small concentrations of thiocyanate this equation becomes

$$
\left(\mathrm{SCN}^{-}\right)=\frac{0.9 t}{1+905 m}
$$

At $t=0.000145$ molar, the error in $\left(\mathrm{SCN}^{-}\right)$due to using this approximate equation is about $0.9 \%$, at $t=0.00142$ molar, the error is about $2 \%$, and at $t=0.0128$ molar the error is about $14 \%$. Equation 8 can be reduced to a more accurate approximation which is

$$
\left(\mathrm{SCN}^{-}\right)=\frac{0.9 t}{1+905 m\left[1-\frac{79 t}{1+905 m}\right]}
$$

At $t=0.000145$ molar the error in $\left(\mathrm{SCN}^{-}\right)$due to using this equation is about $0.007 \%$; at $t=$
0.00142 molar the error is about $0.4 \%$; and at $t=0.012$ molar the error is about $9 \%$. Equations 9 and 10 appear to be simple and useful expressions for the concentration of free thiocyanate in serum as a function of the total thiocyanate and albumin concentrations. Since most clinical experiments involve a value of about 0.001 for $t$ equation 9 is probably sufficiently accurate, but for higher values of $t$ or greater accuracy equation 10 may be used. It should be noted that all concentrations are in moles per kilogram of water, and concentrations measured on a volume basis should be corrected for the water content of blood or serum.

The "thiocyanate space" is calculated by dividing the amount of thiocyanate in the extravascular fluid by the concentration of thiocyanate in this fluid. The concentration of free thiocyanate in the serum is assumed to be the concentration of thiocyanate in the extravascular fluid. The amount of thiocyanate in the plasma and red cells must be subtracted from the total in the body, which necessitates knowing how much thiocyanate is in the blood. This may be calculated if the blood volume and hematocrit are determined. Since the total thiocyanate, $t$, in the serum is known, this multiplied by the weight of serum water (serum volume in liters $\times 0.92 \frac{\text { kilograms water }}{\text { liter of serum }}$ ) gives the amount of thiocyanate in the serum. The values of the $\bar{\nu}$ 's in the blood experiments given in Part $\mathrm{C}$ of Table $\mathrm{I}$ and in Figure 1 were calculated assuming that the concentration of thiocyanate in red cell water was the same as the free thiocyanate in serum. The fairly good agreement of the filled circles with the curve in Figure 1 confirms this assumption essentially though it does appear that some component of red cells, probably hemoglobin, binds thiocyanate to an extent equivalent to about $20 \%$ of the free thiocyanate in serum. ${ }^{7}$ This difference from the curve may be neglected in calculating the total thiocyanate in the red cells since red cell water is only about

7 This is in agreement with the finding of Crandall and Anderson (1) that thiocyanate enters the red cells. If the calculations of the $\bar{\nu}$ 's, in the blood experiments are made assuming thiocyanate does not enter red cells, but is entirely in the serum, the $\bar{\nu}$ 's are about twice as high as the corresponding $\nu^{\prime}$ 's in the serum experiments and the two experiments would be inconsistent. 
$10 \%$ or less of the volume of "thiocyanate space" $(2,17)$. The amount of thiocyanate in the red cells is then found by multiplying the concentration of free thiocyanate in serum, $\left(\mathrm{SCN}^{-}\right)$, by the volume of red cell water (red cell volume in liters $\left.\times 0.65 \frac{\text { kilograms water }}{\text { liter of red cells }}\right)(17)$. Finally, if an appreciable amount of thiocyanate has been excreted in the interval between injection and the determination of serum thiocyanate, this must be subtracted from the total administered. The remaining number of moles of thiocyanate divided by $\left(\mathrm{SCN}^{-}\right)$is the "thiocyanate space," expressed as kilograms of water. As before, all concentrations are in moles per kilogram of water.

If binding by albumin were the only error of the thiocyanate method for measuring extracellular fluid volume, then calculations which have neglected binding would yield values for the "thiocyanate space" which would be about a third smaller than the true value of extracellular fluid volume. But the values obtained will be influenced by at least three other factors: 1) the concentration of albumin in the extravascular compartment; 2) the probable entry of a portion of the thiocyanate into cells; and, 3) the possible lack of equilibrium between thiocyanate in the blood and extravascular space.

1) The higher the concentration of extravascular albumin, the less is the importance of the binding correction. In fact, since $\left(\mathrm{SCN}^{-}\right)$can now be determined, and is the concentration of free thiocyanate outside the vascular compartment as well as inside at equilibrium, one can always determine how much thiocyanate is bound to extravascular albumin if one can determine the amount of this albumin. Calculations which neglect the presence of extravascular albumin will result in values of the "thiocyanate space" higher than the extracellular fluid volume.

2) We have seen that thiocyanate is present in the water in the red cell in concentrations close to that of free thiocyanate in the serum. To what extent thiocyanate enters other cells is unknown, but calculations which neglect such entry will result in values of the "thiocyanate space" which are higher than the true extracellular fluid volume. The same effect will result if certain fluids, such as gastric juice, contain appreciable amounts of thiocyanate, and this is neglected.
3) If the blood thiocyanate is not at equilibrium with the extravascular thiocyanate, the calculation of a "thiocyanate space" has little meaning. If equilibrium is not established, even the concentration of free thiocyanate in blood will be higher than that in the extravascular space and this will make the calculated value of the "thiocyanate space" smaller than the extracellular fluid volume. If sufficient time is allowed, after injection of thiocyanate and before collecting samples, to insure equilibrium, the amount of thiocyanate excreted in that time must be subtracted from the total given, as mentioned above. This is an uncertain procedure since urine thiocyanate is difficult to determine accurately $(18,19)$.

It is, therefore, a relatively simple matter to determine how much thiocyanate in the blood is free to diffuse across semipermeable membranes, and how much is bound to non-diffusible albumin, if one knows the total thiocyanate concentration and the total albumin concentration in serum. Whether the use of these data to calculate extracellular fluid volume is useful will depend on how much thiocyanate enters cells, the magnitude of extravascular fluid albumin, and whether equilibrium is attained.

It is clear that the possibility of binding, as well as the other factors mentioned in this paper, must be considered for any substance used in measuring extravascular fluid volume.

\section{SUM MARY}

1. Distribution experiments of sodium thiocyanate across a cellophane membrane, with normal human serum or blood on one side, have been performed. In the concentration range used to determine extravascular "thiocyanate space," approximately a third of total serum thiocyanate is bound to a non-diffusible component of blood.

2. Comparison of these experiments with work performed on a system containing only water, sodium thiocyanate and crystalline human serum albumin demonstrates that it is serum albumin which binds almost all of this thiocyanate, but that a small amount is bound by another component of serum and red cells.

3. An equation, relating free, unbound serum thiocyanate $\left(\mathrm{SCN}^{-}\right)$, to total serum thiocyanate, $t$, and albumin concentration, $m$, (all expressed as 
moles per kilogram of water) is

$$
\left(\mathrm{SCN}^{-}\right)=\frac{0.9 t}{1+m\left[\frac{787}{1+78.7\left(\mathrm{SCN}^{-}\right)}+\frac{118}{1+3.95\left(\mathrm{SCN}^{-}\right)}\right]}
$$

Two simpler and approximate forms of this equation, sufficiently accurate in the range of thiocyanate concentrations employed clinically, are presented.

4. Although these results permit a more accurate calculation of "thiocyanate space" than heretofore, the relation of this space to extracellular fluid volume is uncertain since 1) the concentration of extravascular albumin is unknown, 2) the extent to which thiocyanate enters cells is unknown, and 3 ) equilibrium between thiocyanate in the serum and in the extravascular fluid may not be attained.

\section{ACKNOWLEDGMENT}

The authors are grateful to Professor George Scatchard for his suggestions and criticism.

\section{BIBLIOGRAPHY}

1. Crandall, L. A., Jr., and Anderson, M. X., Estimation of the state of hydration of the body by the amount of water available for the solution of sodium thiocyanate. Am. J. Digest. Dis. \& Nutrition, 1934, 1, 126.

2. Rutstein, D. D., Thomson, K. J., Tolmach, D. M., Walker, W. H., and Floody, R. J., Plasma volume and "extravascular thiocyanate space" in pneumococcus pneumonia. J. Clin. Invest., 1945, 24, 11.

3. Bowler, R. G., The determination of thiocyanate in blood serum. Biochem. J., 1944, 38, 385.

4. Lavietes, P. H., Bourdillon, J., and Klinghoffer, $K$. A., The volume of the extracellular fluids of the body. J. Clin. Invest., 1936, 15, 261.

5. Rosenbaum, J. D., and Lavietes, P. H., Lipoid-thiocyanate in serum. J. Biol. Chem., 1939, 131, 663.

6. Scatchard, G., Scheinberg, I. H., and Armstrong, S. H., Jr., Physical chemistry of protein solutions.
V. The combination of human serum albumin with thiocyanate ion. J. Am. Chem. Soc., 1950, 72, 540.

7. Pregl, F., Quantitative Organic Micro-Analysis, The Blakiston Co., Philadelphia, 1930.

8. Gitlin, D., Davidson, C. S., and Wetterlow, L. H., The quantitative estimation of serum albumin in human body fluids by direct titration with specific horse antiserum. J. Immunol., 1949, 63, 415.

9. Scatchard, G., Scheinberg, I. H., and Armstrong, S. H., Jr., Physical chemistry of protein solutions. IV. The combination of human serum albumin with chloride ion. J. Am. Chem. Soc., 1950, 72, 535.

10. Cohn, E. J., Hughes, W. L., Jr., and Weare, J. H., Preparation and properties of serum and plasma proteins. XIII. Crystallization of serum albumins from ethanol-water mixtures. J. Am. Chem. Soc., 1947, 69, 1753.

11. Scatchard, G., Batchelder, A. C., and Brown, A., Preparation and properties of serum and plasma proteins. VI. Osmotic equilibria in solutions of serum albumin and sodium chloride. J. Am. Chem. Soc., 1946, 68, 2320.

12. Scatchard, G., and Black, E. S., The effect of salts on the isoionic and isoelectric points of proteins. J. Phys. \& Colloid Chem., 1949, 53, 88.

13. Klotz, I. M., and Urquhart, J. M., The binding of organic ions by proteins; buffer effects. J. Phys. \& Colloid Chem., 1949, 53, 100.

14. Scatchard, G., The attractions of proteins for small molecules and ions. Ann. N. Y. Acad. Sci., 1949, $51,660$.

15. Scatchard, G., and Epstein, L. F., The calculation of the thermodynamic properties and the association of electrolyte solutions. Chem. Rev., 1942, 30, 211.

16. Scatchard, G., Constants of the Debye-Hückel theory. J. Am. Chem. Soc., 1943, 65, 1249.

17. Hawk, P. B., Oser, B. L., and Summerson, W. H., Practical Physiological Chemistry, The Blakiston Co., Philadelphia, 1947, Ed. 12, pp. 412 and 422.

18. Doxiadis, S. A., and Gairdner, D., The estimation of the extracellular fluid volume by the thiocyanate method in children and adults. Clin. Sci., 1946-8, 6, 257.

19. Elkinton, J. R., and Taffel, M., The apparent volume of distribution of sulfocyanate and of sulfanilamide in the dog. Am. J. Physiol., 1942, 138, 126. 